Bond University

Research Repository

\title{
Global money laundering appeal index: application of principal component analysis
}

Tiwari, Milind; Gepp, Adrian; Kumar, Kuldeep

Published in:

Journal of Money Laundering Control

DOI:

10.1108/JMLC-10-2021-0108

Licence:

Other

Link to output in Bond University research repository.

Recommended citation(APA):

Tiwari, M., Gepp, A., \& Kumar, K. (2021). Global money laundering appeal index: application of principal component analysis. Journal of Money Laundering Control. https://doi.org/10.1108/JMLC-10-2021-0108

\footnotetext{
General rights

Copyright and moral rights for the publications made accessible in the public portal are retained by the authors and/or other copyright owners and it is a condition of accessing publications that users recognise and abide by the legal requirements associated with these rights.
}

For more information, or if you believe that this document breaches copyright, please contact the Bond University research repository coordinator. 


\title{
Global Money Laundering Appeal Index: An Application of Principal Component
}

\section{Analysis}

\author{
Milind Tiwari $^{\mathrm{a}}$, Adrian Gepp ${ }^{\mathrm{a}}$, Kuldeep Kumar ${ }^{\mathrm{a}}$
}

${ }^{a}$ Bond University, Australia

\begin{abstract}
The paper aims at developing a global ranking system determining a country's appeal as a destination for money laundering. Using Principal Component Analysis (PCA), four components relating to economic feasibility, financial liberty, government spending, and tax regime were critical in influencing a country's money laundering appeal. It is the first attempt to use a statistical technique to understand the underlying components of a country's money laundering appeal. It could be used to develop more effective preventative strategies.
\end{abstract}

Key Words: Economic growth; Forensic accounting; Money laundering; Principal Component Analysis; Walker Gravity Model

JEL Classification: C38; G32; E39; K42

${ }^{1}$ Corresponding author: Milind Tiwari, Bond University, 14, University Drive, Robina, Queensland - 4226, Australia, e-mail address: mtiwari@bond.edu.au 


\section{Introduction}

Money laundering presents social, economic, and political harm to a country and the global economy by providing an opportunity to launder and reinvest criminal proceeds. Such opportunities lead to economic distortions, erosion of financial sectors, reduced government revenues, and other socioeconomic effects (Barone et al., 2018; Degryse et al., 2019; Walker and Unger, 2009). The extent of economic and financial disruptions can be assessed based on Barone and Masciandaro (2011) estimates. They found money laundering operations to produce legal assets worth USD 108.72 billion in Eastern Europe in 2009. As a result, efforts have been made to measure money laundering flows, construct money laundering risk indicators and uncover other such instances (Basel Institute on Governance, 2014; Collin, 2019; Ferwerda and Kleemans, 2019). Walker (1999) can be regarded as a pioneer in the domain. He postulated a range of factors contributing to the attractiveness of a destination for money laundering. The factors contributing to attractiveness have often been used to estimate the magnitude of money laundering, and there is often a debate around the accuracy of the generated estimates (Collin, 2019).

Efforts have been made to improve the proposed Walker Gravity model, and one such effort in this regard was by Unger et al. (2006). The attractiveness component has been improved only through the addition or removal of variables. No attempts in the literature have been made to use quantitative techniques to develop an index of money laundering appeal. This paper attempts to use a standardized and replicable methodology to condense into a single measure the complex and multifaceted phenomenon of a country's appeal as a destination for money laundering, thus avoiding the difficulty of precisely calculating illicit financial flows.

This paper uses principal component analysis (PCA hereafter), with a mix of standardized and unstandardized components relating to attractiveness, economic freedom, and money 
laundering risk to come up with an index of money laundering appeal (Basel Institute on Governance, 2014; Khan et al., 2018; Kim and Holmes, 2016). Such an index would act as an additional tool to support policymakers and investigators in allocating relevant resources effectively and developing suitable preventative strategies; for banks and professionals, the indicator would improve their due-diligence operations. Such efforts would combat the phenomenon of money laundering responsible for the stagnation of economic growth through tax evasion, corruption, and the creation of non-competitive markets.

\section{Data and Methodology}

The data on 30 variables incorporated for analysis in the paper have been collected for 150 countries. The year chosen for analysis is 2014 to facilitate comparison with the results of an earlier study that used the traditional gravity model to develop the attractiveness of money laundering for countries. In the case of missing variables, the variable information available for the most recent year, past or present, is considered for analysis. Finally, not to exclude countries from analysis, the variables for which no information is available, the variable value is recorded as 0 for that country. Table I below provides the list of variables used for analysis:

\begin{tabular}{|c|c|c|}
\hline Variables & Source & Description \\
\hline $\begin{array}{l}\text { Per Capital Gross Domestic Product } \\
\text { (GDP), Government Expenditure, Tariff } \\
\text { Rate, Income Tax Rate, Corporate Tax } \\
\text { Rate, Tax Burden (\% GDP), Public Debt (\% } \\
\text { GDP), FDI Inflows (in millions), } \\
\text { Unemployment, Inflation (\%), Financial } \\
\text { Deposits }\end{array}$ & $\begin{array}{l}\text { The World Bank } \\
\text { (2020) }\end{array}$ & Assessment of country's macroeconomy \\
\hline Basel AML Score & $\begin{array}{l}\text { Basel Institute on } \\
\text { Governance } \\
\text { (2014) }\end{array}$ & $\begin{array}{l}\text { Ranking countries based on their } \\
\text { assessed risk of money laundering or } \\
\text { terrorist activity to come up with Basel }\end{array}$ \\
\hline
\end{tabular}




\begin{tabular}{|c|c|c|}
\hline & & $\begin{array}{l}\text { Anti-money laundering (AML) Risk } \\
\text { Index }\end{array}$ \\
\hline $\begin{array}{l}\text { Economic } \text { Freedom } \text { Score, Business } \\
\text { Freedom, Financial Freedom, Fiscal } \\
\text { Freedom, Government } \text { Spending, Labor } \\
\text { Freedom, Monetary Freedom, Trade } \\
\text { Freedom }\end{array}$ & $\begin{array}{l}\text { Kim and Holmes } \\
\text { (2016) }\end{array}$ & $\begin{array}{l}\text { Assessment of economic freedom } \\
\text { available to a country's population to } \\
\text { come up with the Index of Economic } \\
\text { Freedom }\end{array}$ \\
\hline $\begin{array}{l}\text { Attractiveness Score, Banking Secrecy } \\
\text { (BS), Conflict (C), Corruption (COR), } \\
\text { Member of Egmont Group (EG), } \\
\text { Government Attitude (AG), Swift Member }\end{array}$ & $\begin{array}{l}\text { Khan et al. (2018); } \\
\text { Walker and Unger } \\
\text { (2009) }\end{array}$ & $\begin{array}{l}\text { Estimate the magnitude of money } \\
\text { laundering for countries subject to their } \\
\text { attractiveness for it }\end{array}$ \\
\hline
\end{tabular}

Table I. List of variables

The use of variables for accessing countries' attractiveness has been limited to estimating the magnitude of money laundering. It presents an opportunity to develop an index of a country's appeal as a destination for it. The rationale to incorporate additional variables stems from works directing attention towards the link between money laundering and economic cycles, economic growth, and taxes (Barone et al., 2018; Johannesen et al., 2016). Such an index would differ from the Basel AML Risk Index and other similar indices that do not measure the country's actual money laundering activity. These indices' focus has been to assess the risk level based on adherence to AML/CTF (Countering Terrorism Financing) standards and other such risk categories. The rankings of such global indices are more suitable in a probabilistic rather than economic sense.

This paper uses PCA to reduce a large number of variables into fewer components representing a specific phenomenon; in this case, money laundering appeal. The data are assessed to determine how the variables covariate. The number of components is selected based on 
accepted standards - the Kaiser-Harris criterion and parallel analysis. The unrotated components are subject to rotation to ensure the pattern of loadings is easier to interpret. The components are then extracted to be normalized and combined in a composite indicator using the proportion of variance explained by each component as weights (Ferwerda and Kleemans, 2019; Watkins, 2006).

\section{Results}

The suitability of the data for PCA is assessed by using a correlation matrix, Kaiser-MeyerOlkin Measure of Sampling Adequacy (KMO), and Barlett's Test of Sphericity (Kaiser, 1960). The high correlation between variables (as seen in Figure 1), a KMO value of 0.768 , and a significant sphericity test, as presented in Table II suggest the data are suitable for PCA.

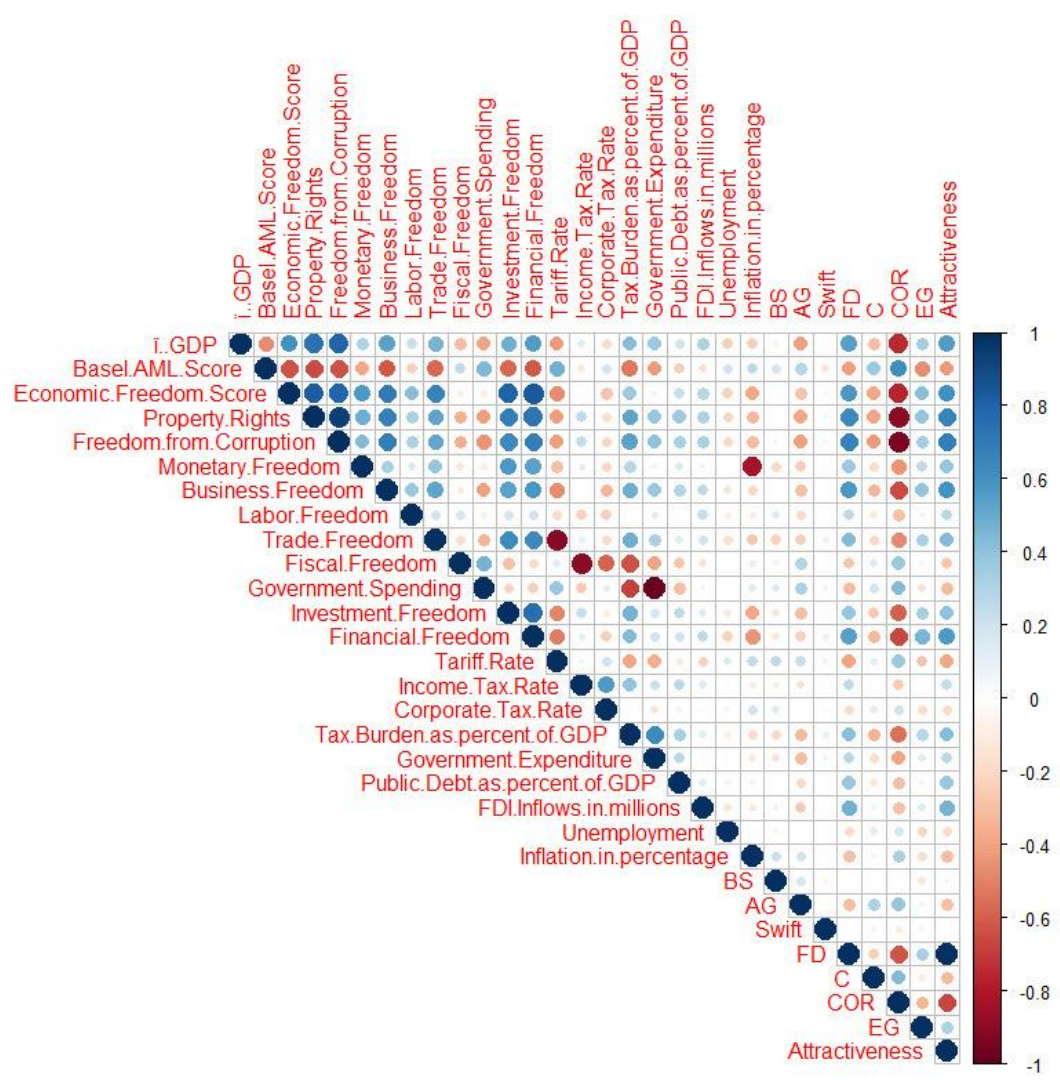

Figure I. Correlogram of variables 


\begin{tabular}{llr}
\hline Kaiser-Meyer-Olkin Measure of Sampling Adequacy. & 0.768 \\
Bartlett's Test of Sphericity & Approx. Chi-Square & 4931.351 \\
& df & 435 \\
& Sig. & 0.000 \\
\hline
\end{tabular}

Table II. KMO and Bartlett's Test of Sphericity

The decision of the number of components to be extracted is based on a mix of Kaiser-criterion (components with eigenvalues $>1$ ) and parallel analysis (Watkins, 2006). The comparison of eigenvalues obtained from Kaiser-criterion and parallel analysis (Table III) are presented below and suggests that four components should be extracted:

\begin{tabular}{lrr|rc}
\hline & \multicolumn{2}{c|}{ Initial Eigenvalues } & \multicolumn{2}{c}{ Random Data Eigenvalues (Parallel Analysis) } \\
\cline { 2 - 5 } Component & \multicolumn{1}{c}{ Total } & \% of variance & Total & Decision \\
\hline 1 & 10.922 & 36.406 & 2.067 & Accept \\
2 & 3.063 & 10.210 & 1.916 & Accept \\
3 & 1.996 & 6.654 & 1.779 & Accept \\
4 & 1.878 & 6.260 & 1.679 & Accept \\
5 & 1.390 & 4.633 & 1.595 & Reject \\
\hline
\end{tabular}

Table III. Comparison of eigenvalues from Kaiser-criterion and Parallel Analysis

The extracted components were subject to varimax rotation to ensure suitable factorization. The output is presented in Table IV and Table V below: 


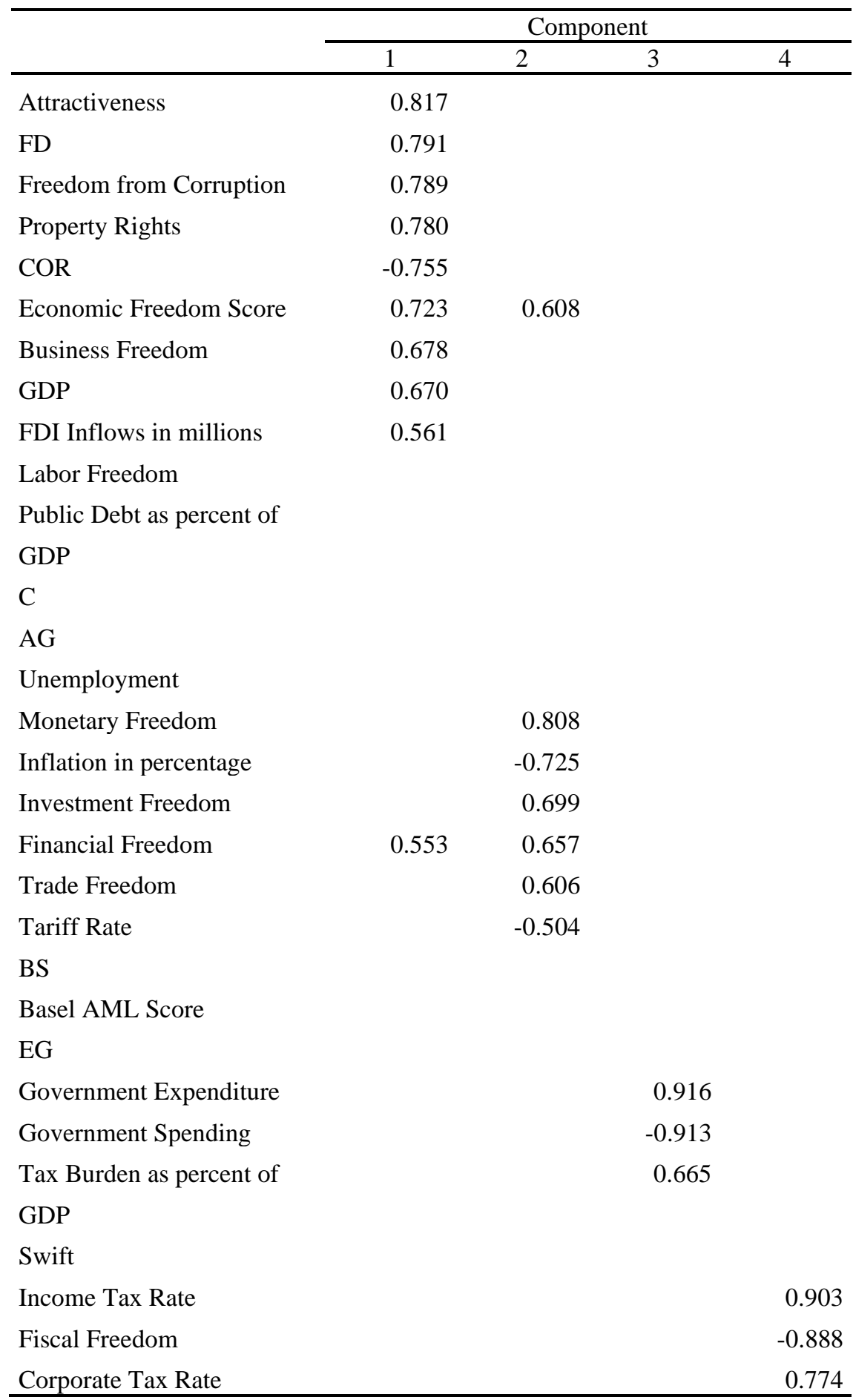

Table IV. Rotated component matrix 


\begin{tabular}{lcc}
\hline \multicolumn{2}{c}{ Variance } \\
\cline { 2 - 3 } Component & \% of variance & Cumulative \% \\
\hline 1 & 22.949 & 22.949 \\
2 & 14.859 & 37.809 \\
3 & 12.228 & 50.037 \\
4 & 9.494 & 59.530 \\
\hline
\end{tabular}

Table V. Variance explained by components

The first component (1) comprised the set of variables related to a country's economic feasibility and explained $22.9 \%$ of the overall variance. The second component (2) explained $14.85 \%$ of the overall variance and included proxies for financial liberty. The expenditure incurred and income source to support it by a country's government are grouped in the third component (3) and explain $12.22 \%$ of the overall variance. Finally, the fourth component (4) relates to a country's tax regime and explains $9.49 \%$ of the overall variance. Consequently, a country's appeal for money laundering can be explained as a follows:

$$
\text { Money Laundering Appeal }=f(E, F, G, T)
$$

Where,

$\mathrm{E}=$ Economic feasibility of a country to invest in

$\mathrm{F}=$ Financial liberty available to people to transact and do business

$\mathrm{G}=$ Government spending

$\mathrm{T}=\mathrm{Tax}$ regime

Each principal component's variance is used as a fraction of the model's overall variance as a weight to obtain the index. The index is normalized using the Min-Max criterion and is expressed as follows: 
Global Money Laundering Appeal Index

$$
=\sum_{j=1}^{4}\left(\mathrm{~S}_{\mathrm{ij}} * \mathrm{w}_{\mathrm{j}}\right)=\left(S_{1 i} * w_{1}\right)+\left(S_{2 i} * w_{2}\right)+\left(S_{3 i} * w_{3}\right)+\left(S_{4 i} * w_{4}\right)
$$

Where the subscript $\mathrm{i}$ indicates the country (150 in total), $\mathrm{j}$ is the component and $\mathrm{w}_{\mathrm{j}}$ is the proportion of variance explained by each component, that is, $w_{1}=22.9 \%, w_{2}=14.85 \%$, $w_{3}=12.22 \%$, and $\mathrm{w}_{4}=9.49 \%$, respectively. $\mathrm{S}_{\mathrm{ij}}$ is the relevant value from the PCA for each component. According to the index, for 2014, the most appealing countries for money laundering were Denmark, Sweden, and the United States, and the least appealing countries were Sudan, Iran, and Iraq (Ranking results are in Table A of the appendix).

\section{Conclusion}

The use of PCA instead of a more theoretical approach is validated by comparing rankings with Khan et al. (2018), and the results were found to be similar. Additionally, Denmark's being found an appealing destination for money laundering in 2014 aligns with a Danish bank's involvement in one of the largest such scandals around the same time (Bjerregaard and Kirchmaier, 2019). The robustness of results can be considered suitable for future work along with the incorporation of more variables. At present, the paper proposes an approach where a complex phenomenon of money laundering appeal can be placed into a single composite indicator, allowing for ranking of geographical locations. Such an index might not only inform national strategies to prevent money laundering but provides an opportunity to use a similar approach to develop more localized hot spot maps that could move analysis at the sub-national level. Finally, concerns about whether a low Basel AML Risk score (Manning et al., 2020) results in lower chances of money laundering are addressed through this paper. 


\section{Acknowledgment}

The authors are grateful to Basel Institute on Governance, The Heritage Foundation, and Wahaj Ahmed Khan for their assistance in providing the data.

\section{Funding}

This work was supported by the Australian Government Research Training Program.

\section{References}

Barone, R., D. Delle Side, D. Masciandaro, 2018. Drug trafficking, money laundering and the business cycle: Does secular stagnation include crime? Metroeconomica 69, 409-426.

Basel Institute on Governance, 2014. Basel AML Index 2014 Report. (Basel Institute on Governance).

Bjerregaard, E., T. Kirchmaier, 2019. The Danske Bank Money Laundering Scandal: A Case Study. Available at SSRN 3446636.

Collin, M., 2019. Illicit Financial Flows: Concepts, Measurement, and Evidence. World Bank Research Observer 35, 44-86.

Degryse, H., A. Karas, K. Schoors, 2019. Relationship lending during a trust crisis on the interbank market: A friend in need is a friend indeed. Economics Letters 182, 1-4.

Ferwerda, J., E.R. Kleemans, 2019. Estimating Money Laundering Risks: An Application to Business Sectors in the Netherlands. European Journal on Criminal Policy and Research 25, 45-62.

Johannesen, N., T. Tørsløv, L. Wier, 2016. Are less developed countries more exposed to multinational tax avoidance? Method and evidence from micro-data. The World Bank Economic Review.

Kaiser, H.F., 1960. The application of electronic computers to factor analysis. Educational and psychological measurement 20, 141-151.

Khan, W.A., S.T. Jawaid, I. Arif, 2018. Where does a nation's wealth go? Evidence from a third world country. Journal of Money Laundering Control 21, 426-476.

Kim, A.B., K.R. Holmes, 2016. 2014 Index of economic freedom. The Heritage Foundation in Partnership with Wall Street Journal.

Manning, M., G.T. Wong, N. Jevtovic, 2020. Investigating the relationships between FATF recommendation compliance, regulatory affiliations and the Basel Anti-Money Laundering Index. Security Journal.

The World Bank, 2020. World Bank Open Data.

Unger, B., M. Siegel, J. Ferwerda, W. de Kruijf, M. Busuioic, K. Wokke, G. Rawlings, 2006. The amounts and the effects of money laundering. Report for the Ministry of Finance 16.

Walker, J., 1999. How Big is Global Money Laundering? Journal of Money Laundering Control 3, 25-37.

Walker, J., B. Unger, 2009. Measuring global money laundering. Review of law and economics $5,821-853$.

Watkins, M.W., 2006. Determining parallel analysis criteria. Journal of modern applied statistical methods 5, 344-346. 